\title{
STUDENT-CENTRED, LECTURER-CENTRED, AND HYBRID TEACHING METHODS: IMPACTS ON ACCOUNTING STUDENTS' TECHNICAL AND SOFT SKILLS
}

\author{
NOOR ADWA SULAIMAN1, * \\ SUHAILY SHAHIMI ${ }^{1}$ \\ ZARINA ZAKARIA ${ }^{1}$
}

Received: 18 February 2020 / Revised: 13 January 2021, 17 May 2021 / Accepted: 31 May 2021

(C) 2021 Faculty of Business and Accountancy, University of Malaya. All rights reserved.

\begin{abstract}
A B S T R A C T
Research aim: This study examines the impacts of teaching methods: student-centred, lecturecentred, and hybrid (lecture-student) on technical and soft skills of accounting students.

Design/ Methodology/ Approach: The impacts are assessed via a structural modelling procedure using Smart PLS based on survey data gathered from accounting students in one public university in Malaysia.

Research findings: Results show the lecturer-centred method impacting the students' technical skills, and the hybrid method impacting students' technical and soft skills. It is evident from the analysis that there is minimal impact of the student-centred teaching method on technical and soft skills and of the lecturer-centred teaching method on soft skills of the accounting students. The results suggest that the hybrid teaching method is the most effective teaching method in enhancing accounting students' technical and soft skills.

Practitioner/ Policy implication: This research could assist universities and policymakers to formulate relevant teaching strategies and approaches to enhance accounting students' competency.
\end{abstract}

Limitation/ Implication: The findings in this study is revisiting and revising the current teaching methods is necessary to prepare future accountants for a career in accounting.

Keywords: Accounting Students, Soft Skills, Teaching Methods, Technical Skills

Type of manuscript: Research paper

JEL Classification: M41, M42, M48, L84

\section{Introduction}

The Malaysian government emphasises the importance of quality human capital with sufficient knowledge and skills for the sustainable economic development of the country and consequently recognising the key role of the accountancy profession in supporting it (CSAP, 2014; EPU, 2015). Nonetheless, the competence of accounting graduates has become a focal point of discussion of relevant groups in recent years (such as regulators, industry players, academics and professional bodies). This is mainly because the universities are claimed to be unsuccessful in producing skills demanded from accounting

${ }^{1}$ Department of Accounting, Faculty of Business and Accountancy, University of Malaya, 50603 Kuala Lumpur, Malaysia *Corresponding author, e-mail: adwa@um.edu.my 
graduates by the job market that then leads to a discussion about how knowledge should be imparted to the accounting students (World Bank 2012; Accounting Deans Council, 2019). This issue has become the Malaysia government's aspiration that needs to be looked at.

In the context of the accounting profession, Dolce et al. (2020) elaborates on the need of accounting graduates to expand and upgrade their skills and competencies to adapt and manage advancements in technology, complex business practices and operations, and complex financial reporting frameworks. This is because greater skills of human capital are needed due to the increasing complexities of the business environment. Under those circumstances, universities are expected to produce accounting graduates that possess a different set of skills that can meet the expectation of employers in the job market. In particular, the importance is now given to not only technical skills but also soft skills of the accounting graduates. As such, the teaching methods of imparting such skills has become a topic of discussion in recent years (Ngoo et al., 2015).

Recent studies suggest that the existence of a gap in perceived skills between employers and accounting graduates is the reason accounting degrees are being criticised for failing to develop these skills to the required level (Shamsuddin et al., 2015; Ngoo et al., 2015; Douglas \& Gammie, 2019). The problem of skill deficiencies among graduates may result from how courses are being taught in universities which do not result in producing the accounting graduates that meet the market demands of the profession (Parker 2001; Arquero et al., 2001; Howieson, 2003). Research evidence suggests that types of teaching methods may affect the students' achievements, including their knowledge and skills (Biggs, 2012; Abeysekara, 2015). Literature in teaching methods is vast, covering various teaching methods, such as student-centred, lecturer-centred and student-lecturer centred; and aspects such as teaching methods with students' effort, learning contexts and academic disciplines, learning environments like teaching tools such as computers and multimedia, and students' performance including grades and soft skills (Clark \& Latshaw, 2012). The current study complements the existing line of research by simultaneously examining the effects of the three different types of teaching methods on technical and soft skills of the accounting students.

By examining the effect of the three teaching methods on the accounting students' technical skills in their major disciplines (financial accounting, management accounting, taxation and auditing) and soft skills (communication, critical thinking and problem solving, leadership and teamwork), it is hoped that the results of this study will provide useful insights to the relevant groups in the accounting education field in Malaysia about the impacts of different teaching methods on the accounting students' competency. The empirical evidence would also be able to provide an answer to their 
concerns regarding the competency of the accounting graduates. In addition, this study adds knowledge to the literature by providing empirical evidence on the impact of teaching methods on specific sets of soft skills and technical skills of accounting graduates in its major courses or disciplines.

The next section provides a brief review of the literature. Section 2 outlines the methodology of the study. Section 4 provides and discusses the findings of the study, while the final section concludes the study.

\section{Background and Literature Review}

\subsection{The Malaysia Accounting Competency Framework}

The accountancy profession in Malaysia is regulated through the Accountants Act, 1967 that prescribes among others membership, regulation and enforcement of accounting profession via a professional body that is the Malaysian Institute of Accountants (MIA). The responsibilities of the Institute include determining qualifications for membership admission, providing and reviewing accountants' education and training, regulating accounting practices and promoting the accountancy profession's interests. In an effort to enhance the qualifications and competency of accounting graduates, the Ministry of Higher Education of Malaysia has been working together with the Steering Committee for the Review of Direction Accounting Program to review structure and contents of the accounting programmes offered by universities in Malaysia to ensure that it meets the demands of the business world. The review exercise covered the re-evaluation of graduate competencies in technical and soft skills, curriculum contents and learning approaches (MOHE, 2015).

The competency of accounting graduates has been criticized for not meeting the required competency level by the World Bank in 2012 in its report - the Observance of Standards and Codes in Accounting and Auditing (World Bank, 2012). Subsequently, a committee (Committee to Strengthen the Accountancy Profession [CSAP]) was formed with the objective of identifying actions for necessary improvements in the profession. The CSAP recognizes the role of universities in ensuring that the supply of adequate competent professional accountants meets the changing landscape of business environments while supporting Malaysia's economic development. The report emphasizes the importance of broader skills (comprising of technical and soft skills) that need to be obtained by the accounting graduates which can be acquired by improving inter alia learning and teaching infrastructure, personal development of lecturers and teaching pedagogy.

Following this, the MIA Education Board has issued the MIA competency framework (MIA CF) in 2020 that outlines a set of principles that characterizes the baseline competencies and sets of skills required by accountancy professionals in three levels of proficiency: foundation (accounting technician), 
intermediate (accountant), and advanced (chartered accountant) as suggested by the International Education Standards (IES) issued by the International Federation of Accountants (IFAC) for its members (MIA CF, 2020). The MIA CF acknowledges that accounting education programs offered by universities are important in ensuring appropriate professional competence of aspiring professional accountants. The MIA CF prescribes the benchmark for competency recognition that is made up of technical competence in various areas of business and accounting, such as financial accounting and reporting, audit and assurance, taxation and management accounting. The proficiency levels cover, among other things, the ability of accounting graduates to prepare financial statements in accordance with the accounting standards, interpret financial statements, apply management accounting techniques to support management's decision, apply relevant auditing standards and regulation in audit performance, and prepare tax calculation for individuals and companies.

In addition, professional values, ethics, attitudes, and professional skills (such as intellectual, interpersonal and communication skills) are also recognized as part of the competency framework. Accounting graduates are expected to be able to apply critical thinking in solving business and accounting issues, to communicate in a clear and concise manner during presentations and discussions, and to assess and act appropriately in circumstances that may create conflict of interests that affect professional behaviour and ethics.

Overall, the framework emphasized that technical and soft skills are important for the aspiring chartered accountants that are initially acquired during theoretical education, i.e., their university years. Such skills will be further strengthened when the graduates join the workforce during on-the-job training and from practical experience. Given the background of Malaysia's accounting competency framework, this study examines the effects of teaching methods carried out in a university in Malaysia and the effect these methods have on the students' technical and soft skills.

\subsection{Literature Review}

This section provides a brief review of the literature related to students' skills covering both technical and soft skills, as well as teaching methods.

\subsubsection{Students' Skills}

Students' skills in this study encompasses both technical skills as well as soft skills. Technical skill refers to skills used in a particular line of work that enables an individual to complete a specific task. In this study, it refers to the major areas of accounting subjects covered in the accounting undergraduate programme, namely Financial Accounting, Management Accounting, Accounting Information System and Taxation. Whilst technical skills are 
necessary for accountants, they are not sufficient for their future careers in the accountancy profession (MIA CF, 2020). Prior research has identified nontechnical skills, i.e., soft skills required by accountants as identified by the International Education Standard (IES), namely intellectual skills, personal skills, interpersonal and communication skills as well as organisational and business management skills (Ahmad, 2019; Abeysekara, 215; IFAC, 2010;). As such, enhancing soft skills of the accounting graduates in Malaysia is crucial in ensuring that they are able to maintain their competitiveness (Ahmad, 2019; Maelah et al., 2012; Clark, 2015) and similar points have been emphasised for graduates in various developed nations, such as America (Albrecht \& Sack, 2000) Australia and British (Gammie et al., 2002; Howieson, 2003) as well as South Africa (Barac, 2009; Stainbank, 2009). In this study, soft skills are defined as the "interpersonal, human, people or behavioural skills needed to apply technical skills and knowledge in the workplace" (Weber et al., 2009, p. 356; Villiers, 2010). Prior studies have also established that soft skills have become increasingly important for promotion to higher levels, and that accountant must also possess a high level of technical competence throughout the promotional process in order to reach the point of consideration for partnership (Dolce et al., 2020; Ahmad, 2019; Blanthorne et al., 2005). Within Malaysia National Philosophy of Education, the main goal of education is to produce a balanced and harmonious individual who is intellectually, spiritually, emotionally and physically (MOE, 2013). In instilling soft skill amongst students, it is recognized that teaching methods can influence the development of several social intellectual abilities such as cooperation, leadership, responsibility, self-confidence, independence, ability to make decisions and communication skills (Kermis \& Kermis, 2009). For this reason, this study intends to evaluate which teaching method will mostly influence soft skills mastered by students.

\subsubsection{Teaching Methods}

According to Ayeni (2011), teaching is a process that involves bringing about desirable changes in learners so as to achieve specific outcomes. In ensuring that the teaching method used is effective, Adunola (2011) emphasised that teachers need to be conversant with numerous teaching strategies that recognise the complexity of the concepts to be covered. In assessing this, substantial research on the effectiveness of teaching methods indicates that the quality of teaching is often reflected by the achievements of learners (Yue, 2020; Reschiwati \& Zahri, 2019; Ganyaupfu, 2013).

Theories of learning encompass behaviourism, constructivism and social constructivism with different pedagogical approaches being associated to the different process of learning. The behaviourism theory of learning focuses on lecturer-centred learning which emphasises the key role of educator in student 
learning. The constructivism theory of learning, on the other hand, is associated with student-centred learning that emphasises the active role of the individual student in the learning process. The social constructivism theory of learning and pedagogy is a lecturer-student interactive method or also commonly cited as a hybrid method which combines teacher-centred and student-centred approaches of learning. The following will describe attributes of the respective methods.

Student-Centred Method - In this method, students play a significant role in designing their curriculum and the lecturer, on the other hand, plays the role of a facilitator or guide who helps students achieve their goals (Serin, 2018; Wolk, 2010). Brown (2008) claimed that the student-centred learning approach gives students ownership over their learning and helps them make necessary decisions and value judgements about the relevance of the content and the methods of teaching to their lives and interests. The teaching method is regarded more effective since it does not centralize the flow of knowledge from the lecturer to the student (Lindquist, 1995). The approach also motivates goaloriented behaviour among students, hence the method is very effective in improving student achievement (Serin, 2018; Slavin, 1996).

Lecturer-Centred Method - In this method, stude'nts are obtaining information from the lecturer without direct engagement about the subject matter (Serin, 2018; Boud \& Feletti, 1999). Under this method, students simply obtain information from the lecturer without building their engagement level with the subject being taught (Serin, 2018; Boud \& Feletti, 1999). There are several elements of this method which include teacher talk exceeds student talk during instruction, instruction is mostly to the entire class, textbooks guide what is being taught in class and each episode within the lesson is determined by the teacher (Ramsarghey, 2020; Kok, 1994). Using this method, lecturers will be able to focus on ensuring that contents are passed on to the students, in which the relevant information is given out and not discovered by the students on their own. This has been argued as more practical and more time efficient. (Serin, 2018). Whilst traditional, this method tends to have positive effects on the performance of the students (Serin, 2018). Kok (1994) related this to the Eastern way of upbringing which has 'a deep reverence for the accumulated wisdom of their elders' and the belief that 'teachers always know best and they know all'.

Hybrid i.e., lecturer-student interactive method - Ganyaupfu (2013) defined the lecturer-student interactive method as a teaching method that applies the strategies used by both teacher-centred and student-centred approaches. In this method, information is produced and remembered better by the students (FarrWharton et al., 2018; Jacoby, 1978; McDaniel et al., 1978; Slamecka \& Graf, 1978). The method encourages the students to search for relevant knowledge rather than only the lecturer transferring the transmission of information to the 
learners. As such, research evidence on teaching approaches maintains that this teaching method is effective in improving students' academic performance (Farr-Wharton et al., 2018; Damodharan \& Rengarajan, 1999). Both Ramsarghey (2020) as well Adebayo et al. (2015) also claimed that the interactive teaching strategy facilitates effective learning among students of diverse learning styles.

The recent years has witnessed how teaching method has evolved (Ramsarghey, 2020; Warner \& Palmer, 2015), however, there appears to be insufficient evidence of how different educational approaches to accounting education has been adopted by accounting educators (Adler et al., 2000). Hence, it is pertinent to evaluate which methods do significantly affect the students' performance. Acknowledging that all three methods of teaching described above, undertaken effectively, can positively affect the performance of students, both in their technical and soft skills. As such, the following hypothesis are proposed:

H1: There is a positive relationship between the student-centred teaching method and students' technical skills.

H2: There is a positive relationship between the student-centred teaching method and students' soft skills.

H3: There is a positive relationship between the lecturer-centred teaching method and students' technical skills.

H4: There is a positive relationship between the lecturer-centred teaching method and students' soft skills.

H5: There is a positive relationship between the hybrid teaching method and students' technical skills.

H6: There is a positive relationship between the hybrid teaching method and students' soft skills.

\section{Research Methodology}

\subsection{Sample and Instruments}

The data used in this study were collected through survey questionnaires among the second to fourth year accounting students at public universities in Malaysia. A seven-point Likert scale was used in the questionnaires to denote frequency of occurrence or agreement, where 1 denotes an infrequent occurrence or disagreement and 7 for frequent occurrence or agreement. The questions were adapted from previous empirical studies with a slight modification where necessary. A total of 287 registered students in second year and above is the criteria for selecting the respondents with the justification that students would be able to develop technical and soft skills after more than six months learning the skills (Gallo, 2012). The sample was collected via a non- 
probability convenience sampling approach. Of the 287 questionnaires, a total of 121 responses were returned, yielding a response rate of $42 \%$ that compares favourably to the response rate for other recent studies of similar nature (Ganyaupfu, 2013; Ismail, 2013; Adunola, 2011).

Prior to data analysis, each of the variables used in the model was examined for accuracy of data entry, missing values, and fit between their distributions using SPSS (Pallant, 2011). This study adapted the measurement scales used by Nadkarni (2003), O'Leary and Stewart (2013) and Watts and Schaur (2011) to measure teaching methods. Descriptive statistics on all variables were performed and illustrate the values of mean and standard deviation. The data collected were analysed using a SmartPLS software. SmartPLS is a type of Structural Equation Modeling that can examine multiple relationships simultaneously. These relationships can then be interpreted into objective results either to support or reject the hypotheses that were set earlier on.

\subsection{Research Framework}

According to theories of learning, pedagogical approaches affect student learning and performance in terms of technical skills and soft skills. The research framework (Figure 1) depicts the relationship between three independent variables and two dependent variables of the study. This study examines the effects of the student-centred teaching method, the lecturercentred teaching method and the hybrid teaching method on technical skills and soft skills.

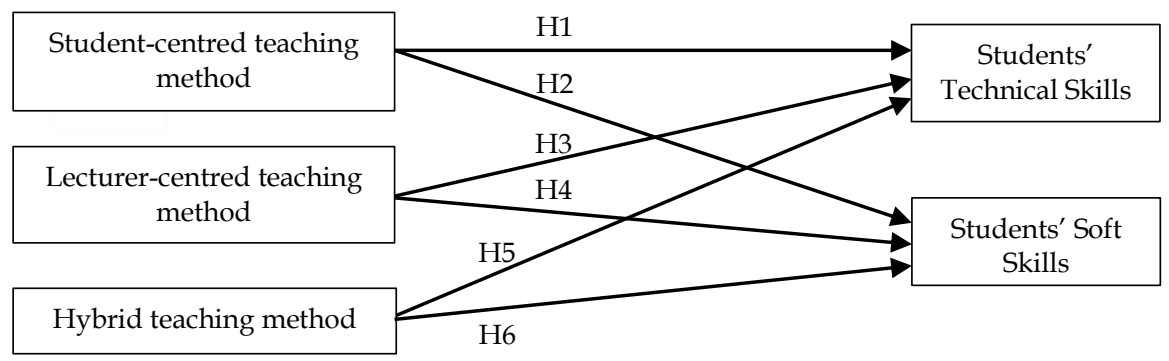

Figure 1 Research Model

\section{Data Analysis and Results}

This study employed the Structural Equation Modeling-Variance Based (SEMVB) through Partial Least Squares (PLS) method to analyse the research model using SmartPLS 3-.0 software (Ringle et al., 2015). After the demographic profiling of respondents, this study followed the two-stage analytical technique recommended by Anderson and Gerbing (1988) and Hair et al. (2017), starting 
with the measurement model assessment (validity and reliability), followed by the structural model assessment (testing the hypothesized relationships). Schumacker and Lomax (2004) and Hair et al. (2010) state that the two-step assessment procedure, which includes both measurement and structural models, has an advantage over the one step assessment procedure. The measurement model specifies how each construct is measured, while the structural model specifies how the variables are related to each other in the structural model (Hair et al., 2017). According to Barclay et al. (1995), the main reason for choosing PLS as a statistical method for this study is that PLS offers simultaneous analysis of both measurement and structural model leading to more accurate estimates. Consistent with Neupane et al. (2014) and Ismail et al. (2012), PLS is a method for data analysis that has been used in various fields of computer science, marketing, accounting, management and psychology. Other research (Hanafi, 2007; Chin, 1998; Henseler et al., 2009; Lehner \& Haas, 2010; Wetzels et al., 2009) state that PLS can be used when the sample size is relatively small by which in this study, the sample size is 121 .

\subsection{Demographic Profile of Respondents}

The demographic profile of the respondents is shown in Table 1. Table 1 presents the information of the respondents' background.

Table 1 Summary of Demographic Profile of Respondents

\begin{tabular}{llcc}
\hline Demographics & Category & Frequency & Percentage \\
\hline Current Year of Study & 2nd year & 13 & 10.7 \\
& $3^{\text {rd }}$ year & 85 & 70.2 \\
& $4^{\text {th }}$ year & 28 & 19.0 \\
\hline Age & Less than 20 years & 9 & 7.4 \\
& 21-30 years & 107 & 88.4 \\
& 31-40 years & 5 & 4.1 \\
\hline Latest CGPA & Below 2.5 & 15 & 12.4 \\
& $2.5-2.99$ & 66 & 54.5 \\
& $3.0-3.49$ & 26 & 21.5 \\
& $3.5-2.75$ & 14 & 11.6 \\
& 3.75 and above & - & - \\
\hline Nationality & Malay & 62 & 51.2 \\
& Chinese & 41 & 33.9 \\
& Indian & 13 & 10.7 \\
& Others & 5 & 4.1 \\
\hline Gender & Male & 43 & 35.5 \\
& Female & 78 & 64.5 \\
\hline
\end{tabular}

The respondents' demographic characteristics includes the respondents' current year of study, age, latest CGPA, race and gender. As stated in the table, the majority of respondents were female, $64.5 \%$ and $35.5 \%$ are male. On the 
other hand, majority of the respondents were Malay $(51.2 \%)$ followed by Chinese $33.9 \%$ and then Indian, $10.7 \%$ and Others, $4.1 \%$. The survey illustrated a majority of the respondents, $88.4 \%$, were aged between 21 to 30 years old followed by the age group of less than 20 years old $(7.4 \%)$ and 31 to 40 years old, $(4.1 \%)$ with the mean and standard deviation values of 1.9669 and 0.3400 respectively. Next, majority of the respondents are third-year students $(70.2 \%)$, followed by fourth-year students (19\%) and second-year students (10.7\%). Most respondents are in the category of latest cumulative grade point average (CGPA) of 2.5-2.99.

\subsection{Measurement Model of Assessment}

Assessment of the measurement model was done through construct reliability as well as validity (including convergent and discriminant validity). For construct reliability, this study tested the individual Cronbach's alpha coefficients to measure the reliability of each of the core variables in the measurement model. The results indicate that all individual Cronbach's alpha coefficients ranged from 0.613 to 0.937 . This coefficient varies from 0 to 1 , and a value of 0.6 or less generally indicates unsatisfactory internal consistency reliability (Malhotra, 2010). However, according to Cortina (1993), the value 0.5 and above is considered acceptable for showing satisfactory internal consistency reliability. Additionally, for testing construct reliability, all the composite reliability (CR) values ranging from 0.865 to 0.983 were higher than 0.7 (Kline, 2010; Gefen et al., 2000), which adequately indicates that construct reliability is fulfilled as shown in Table 2. Therefore, the achieved Cronbach's alpha and CR for all constructs were considered to be sufficiently error-free.

Factor loading was used to test indicator reliability. High loadings on a construct indicate that the associated indicators seem to have much in common, which is captured by the construct (Hair et al., 2017). Factor loadings greater than 0.50 were considered to be very significant (Hair et al., 2010). The loadings for all items exceeded the recommended value of 0.5 as shown in Table 2, except for 42 items which were eliminated from the scale due to low loadings. The loading for the remaining items in the model has fulfilled all the requirements. For testing convergent validity (the extent to which a measure correlates positively with alternative measures of the same construct), this study used the average variance extracted (AVE), and it indicated that all AVE values were higher than the suggested value of 0.50 (Hair et al., 2010) ranging from 0.525 to 0.569 . The convergent validity for all constructs has been successfully fulfilled and adequate convergent validity exhibited as Table 2 depicts.

The discriminant validity (the degree to which items differentiate among constructs or measure distinct concepts) of the measurement model was checked using three criteria, namely cross-loadings, Fornell-Larcker criterion and the heterotrait-monotrait ratio (HTMT). According to Hair et al. (2017), the 
cross-loadings are typically the first approach to assess discriminant validity of the indicators.

Table 2 Mean, Standard Deviation, Loading, Cronbach's Alpha, CR and AVE

\begin{tabular}{|c|c|c|c|c|c|c|c|}
\hline Construct & Item & $\begin{array}{c}\text { Loading } \\
(>0.5)\end{array}$ & Mean & SD & $\begin{array}{l}\text { Cronbach's } \\
\text { Alpha }(>0.6)\end{array}$ & $\begin{array}{c}\text { CR } \\
(>0.7)\end{array}$ & $\begin{array}{c}\text { AVE } \\
(0.5)\end{array}$ \\
\hline $\begin{array}{l}\text { Student- } \\
\text { centred } \\
\text { teaching } \\
\text { method }\end{array}$ & $\begin{array}{l}\text { DD1 } \\
\text { DD10 } \\
\text { DD11 } \\
\text { DD12 } \\
\text { DD13 } \\
\text { DD14 } \\
\text { DD15 } \\
\text { DD16 } \\
\text { DD17 } \\
\text { DD18 } \\
\text { DD19 } \\
\text { DD2 } \\
\text { DD20 } \\
\text { DD3 } \\
\text { DD4 } \\
\text { DD5 } \\
\text { DD6 } \\
\text { DD7 } \\
\text { DD8 } \\
\text { DD9 }\end{array}$ & $\begin{array}{c}\text { deleted } \\
\text { deleted } \\
\text { deleted } \\
\text { deleted } \\
\text { deleted } \\
\text { deleted } \\
\text { deleted } \\
0.661 \\
\text { deleted } \\
\text { deleted } \\
\text { deleted } \\
\text { deleted } \\
\text { deleted } \\
\text { deleted } \\
0.810 \\
\text { deleted } \\
\text { deleted } \\
\text { deleted } \\
\text { deleted } \\
0.759\end{array}$ & 4.844 & 0.509 & 0.613 & 0.789 & 0.556 \\
\hline $\begin{array}{l}\text { Lecturer- } \\
\text { centred } \\
\text { teaching } \\
\text { method }\end{array}$ & $\begin{array}{l}\text { D10 } \\
\text { D11 } \\
\text { D12 } \\
\text { D1a } \\
\text { D1b } \\
\text { D2 } \\
\text { D3 } \\
\text { D4 } \\
\text { D5 } \\
\text { D6 } \\
\text { D7 } \\
\text { D8 } \\
\text { D9 } \\
\end{array}$ & $\begin{array}{c}0.696 \\
\text { deleted } \\
\text { deleted } \\
\text { deleted } \\
0.632 \\
\text { deleted } \\
0.696 \\
0.747 \\
0.864 \\
0.760 \\
\text { deleted } \\
\text { deleted } \\
0.65\end{array}$ & 5.566 & 0.666 & 0.846 & 0.884 & 0.525 \\
\hline $\begin{array}{l}\text { Hybrid } \\
\text { teaching } \\
\text { method }\end{array}$ & $\begin{array}{l}\text { DLS1 } \\
\text { DLS10 } \\
\text { DLS11 } \\
\text { DLS12 } \\
\text { DLS13 } \\
\text { DLS14 } \\
\text { DLS15 } \\
\text { DLS16 } \\
\text { DLS2 } \\
\text { DLS3 } \\
\text { DLS4 } \\
\text { DLS5 } \\
\text { DLS6 } \\
\text { DLS7 } \\
\text { DLS8 } \\
\text { DLS9 }\end{array}$ & $\begin{array}{c}\text { deleted } \\
\text { deleted } \\
\text { deleted } \\
\text { deleted } \\
\text { deleted } \\
\text { deleted } \\
\text { deleted } \\
\text { deleted } \\
0.736 \\
0.697 \\
\text { deleted } \\
0.698 \\
0.725 \\
0.731 \\
0.745 \\
0.763\end{array}$ & 5.198 & 0.585 & 0.853 & 0.888 & 0.530 \\
\hline
\end{tabular}


Table 2 (Continued)

\begin{tabular}{|c|c|c|c|c|c|c|c|}
\hline Construct & Item & $\begin{array}{c}\text { Loading } \\
(>0.5)\end{array}$ & Mean & SD & $\begin{array}{c}\text { Cronbach's } \\
\text { Alpha }(>0.6)\end{array}$ & $\begin{array}{c}C R \\
(>0.7)\end{array}$ & $\begin{array}{l}\text { AVE } \\
(0.5)\end{array}$ \\
\hline $\begin{array}{l}\text { Students' } \\
\text { Technical } \\
\text { Skills }\end{array}$ & $\begin{array}{l}\text { E1 } \\
\text { E10 } \\
\text { E11 } \\
\text { E12 } \\
\text { E13 } \\
\text { E2 } \\
\text { E3 } \\
\text { E4 } \\
\text { E5 } \\
\text { E6 } \\
\text { E7 } \\
\text { E8 } \\
\text { E9 }\end{array}$ & $\begin{array}{c}0.809 \\
\text { deleted } \\
0.766 \\
0.662 \\
0.749 \\
0.806 \\
0.704 \\
0.748 \\
0.757 \\
0.797 \\
0.733 \\
\text { deleted } \\
\text { deleted }\end{array}$ & 5.114 & 0.726 & 0.916 & 0.929 & 0.569 \\
\hline $\begin{array}{l}\text { Students' } \\
\text { Soft Skills }\end{array}$ & $\begin{array}{l}\text { EE1 } \\
\text { EE10 } \\
\text { EE11 } \\
\text { EE12 } \\
\text { EE13 } \\
\text { EE14 } \\
\text { EE15 } \\
\text { EE16 } \\
\text { EE17 } \\
\text { EE18 } \\
\text { EE19 } \\
\text { EE2 } \\
\text { EE20 } \\
\text { EE21 } \\
\text { EE22 } \\
\text { EE3 } \\
\text { EE4 } \\
\text { EE5 } \\
\text { EE6 } \\
\text { EE7 } \\
\text { EE8 } \\
\text { EE9 }\end{array}$ & $\begin{array}{c}0.637 \\
0.756 \\
\text { deleted } \\
0.811 \\
0.692 \\
0.714 \\
0.783 \\
0.812 \\
0.71 \\
0.794 \\
0.78 \\
\text { deleted } \\
\text { deleted } \\
0.718 \\
0.659 \\
\text { deleted } \\
\text { deleted } \\
\text { deleted } \\
0.655 \\
\text { deleted } \\
0.682 \\
0.714 \\
\end{array}$ & 5.390 & 0.688 & 0.937 & 0.944 & 0.533 \\
\hline
\end{tabular}

Note: $\mathrm{SD}=$ Standard Deviation, $\mathrm{CR}=$ Composite Reliability, AVE = Average Variance Extracted.

The measurement used is seven-point scale ranging from:1 (strongly disagree) to 7 (strongly agree)

As shown in Table 3, the cross-loading criterion fulfils the requirements because the indicators outer loadings on a construct were higher than all crossloadings with other constructs (bold values). The results of discriminant validity by using the Fornell-Larcker criterion is shown in Table 4, where the square root of the AVEs on the diagonals, as represented by the bolded values, are higher than the correlations between constructs (corresponding row and column values). This indicates that the constructs are strongly related to their respective indicators compared to other constructs of the model (Fornell \& Larcker, 1981; Chin, 1998). Hence, suggesting a good discriminant validity (Hair et al., 2017). In addition, the correlation between exogenous constructs is 
less than 0.85 (Awang, 2014). Thus, the discriminant validity of all constructs is fulfilled.

Table 3 Results of Discriminant Validity by the Cross Loadings

\begin{tabular}{|c|c|c|c|c|c|}
\hline & $\begin{array}{l}\text { Student- } \\
\text { centred } \\
\text { teaching } \\
\text { method }\end{array}$ & $\begin{array}{l}\text { Lecture- } \\
\text { centred } \\
\text { teaching } \\
\text { method }\end{array}$ & $\begin{array}{l}\text { Hybrid } \\
\text { teaching } \\
\text { method }\end{array}$ & $\begin{array}{c}\text { Students' } \\
\text { Technical Skills }\end{array}$ & $\begin{array}{l}\text { Students' Soft } \\
\text { Skills }\end{array}$ \\
\hline DD16 & 0.661 & 0.282 & 0.238 & 0.151 & 0.249 \\
\hline DD4 & 0.810 & 0.454 & 0.356 & 0.387 & 0.305 \\
\hline DD9 & 0.759 & 0.339 & 0.251 & 0.378 & 0.300 \\
\hline D10 & 0.421 & 0.696 & 0.228 & 0.331 & 0.143 \\
\hline D1b & 0.371 & 0.632 & 0.254 & 0.439 & 0.201 \\
\hline D3 & 0.309 & 0.696 & 0.283 & 0.381 & 0.238 \\
\hline D4 & 0.218 & 0.747 & 0.340 & 0.337 & 0.283 \\
\hline D5 & 0.409 & 0.864 & 0.332 & 0.441 & 0.296 \\
\hline D6 & 0.366 & 0.76 & 0.367 & 0.443 & 0.264 \\
\hline D9 & 0.387 & 0.65 & 0.322 & 0.405 & 0.285 \\
\hline DLS2 & 0.236 & 0.343 & 0.736 & 0.498 & 0.573 \\
\hline DLS3 & 0.222 & 0.325 & 0.697 & 0.499 & 0.458 \\
\hline DLS5 & 0.336 & 0.264 & 0.698 & 0.401 & 0.364 \\
\hline DLS6 & 0.435 & 0.307 & 0.725 & 0.467 & 0.615 \\
\hline DLS7 & 0.242 & 0.342 & 0.731 & 0.425 & 0.627 \\
\hline DLS8 & 0.246 & 0.317 & 0.745 & 0.474 & 0.526 \\
\hline DLS9 & 0.241 & 0.26 & 0.763 & 0.550 & 0.529 \\
\hline E1 & 0.334 & 0.369 & 0.535 & 0.809 & 0.474 \\
\hline E11 & 0.374 & 0.485 & 0.524 & 0.766 & 0.478 \\
\hline E12 & 0.35 & 0.412 & 0.401 & 0.662 & 0.347 \\
\hline E13 & 0.386 & 0.484 & 0.500 & 0.749 & 0.377 \\
\hline E2 & 0.347 & 0.429 & 0.584 & 0.806 & 0.455 \\
\hline E3 & 0.252 & 0.262 & 0.421 & 0.704 & 0.389 \\
\hline E4 & 0.314 & 0.355 & 0.476 & 0.748 & 0.515 \\
\hline E5 & 0.244 & 0.455 & 0.47 & 0.757 & 0.513 \\
\hline E6 & 0.402 & 0.508 & 0.516 & 0.797 & 0.46 \\
\hline E7 & 0.261 & 0.372 & 0.466 & 0.733 & 0.503 \\
\hline EE1 & 0.259 & 0.259 & 0.575 & 0.508 & 0.637 \\
\hline EE10 & 0.336 & 0.250 & 0.611 & 0.479 & 0.756 \\
\hline EE12 & 0.296 & 0.224 & 0.626 & 0.475 & 0.811 \\
\hline EE13 & 0.18 & 0.233 & 0.581 & 0.474 & 0.692 \\
\hline EE14 & 0.222 & 0.199 & 0.529 & 0.428 & 0.714 \\
\hline EE15 & 0.317 & 0.323 & 0.523 & 0.438 & 0.783 \\
\hline EE16 & 0.296 & 0.346 & 0.652 & 0.521 & 0.812 \\
\hline EE17 & 0.251 & 0.195 & 0.452 & 0.404 & 0.710 \\
\hline EE18 & 0.285 & 0.269 & 0.510 & 0.387 & 0.794 \\
\hline EE19 & 0.352 & 0.223 & 0.466 & 0.324 & 0.78 \\
\hline EE21 & 0.373 & 0.302 & 0.359 & 0.304 & 0.718 \\
\hline EE22 & 0.335 & 0.279 & 0.366 & 0.346 & 0.659 \\
\hline EE6 & 0.252 & 0.200 & 0.462 & 0.393 & 0.655 \\
\hline EE8 & 0.308 & 0.251 & 0.566 & 0.460 & 0.682 \\
\hline EE9 & 0.181 & 0.21 & 0.592 & 0.490 & 0.714 \\
\hline
\end{tabular}

Note: DD: Student-centred teaching method, D: Lecturer-centred teaching method, DLS: Hybrid teaching method, E: Students' technical skills, EE: Students' soft skills 
Table 4 Results of discriminant validity by Fornell-Larcker criterion

\begin{tabular}{|c|c|c|c|c|c|}
\hline Factors & $\begin{array}{l}\text { Hybrid } \\
\text { teaching } \\
\text { method }\end{array}$ & $\begin{array}{l}\text { Lecturer- } \\
\text { centred } \\
\text { teaching } \\
\text { method }\end{array}$ & $\begin{array}{l}\text { Student- } \\
\text { centred } \\
\text { teaching } \\
\text { method }\end{array}$ & $\begin{array}{l}\text { Students' } \\
\text { Soft Skills }\end{array}$ & $\begin{array}{l}\text { Students' } \\
\text { Technical } \\
\text { Skills }\end{array}$ \\
\hline $\begin{array}{l}\text { Hybrid } \\
\text { teaching } \\
\text { method }\end{array}$ & 0.728 & & & & \\
\hline $\begin{array}{l}\text { Lecturer- } \\
\text { centred } \\
\text { teaching } \\
\text { method }\end{array}$ & 0.425 & 0.724 & & & \\
\hline $\begin{array}{l}\text { Student- } \\
\text { centred } \\
\text { teaching } \\
\text { method }\end{array}$ & 0.382 & 0.491 & 0.746 & & \\
\hline $\begin{array}{l}\text { Students' } \\
\text { Soft Skills }\end{array}$ & 0.734 & 0.344 & 0.384 & 0.73 & \\
\hline $\begin{array}{l}\text { Students' } \\
\text { Technical } \\
\text { Skills }\end{array}$ & 0.653 & 0.554 & 0.437 & 0.598 & 0.754 \\
\hline
\end{tabular}

Table 5 Results of Discriminant Validity by HTMT

\begin{tabular}{llllll}
\hline Factors & $\begin{array}{l}\text { Hybrid } \\
\text { teaching } \\
\text { method }\end{array}$ & $\begin{array}{l}\text { Lecturer- } \\
\text { centred } \\
\text { teaching } \\
\text { method }\end{array}$ & $\begin{array}{l}\text { Student- } \\
\text { centred } \\
\text { teaching } \\
\text { method }\end{array}$ & $\begin{array}{l}\text { Students' } \\
\text { Soft Skills }\end{array}$ & $\begin{array}{l}\text { Students' } \\
\text { Technical } \\
\text { Skills }\end{array}$ \\
\hline $\begin{array}{l}\text { Hybrid } \\
\text { teaching } \\
\text { method }\end{array}$ & & & & \\
$\begin{array}{l}\text { Lecturer- } \\
\text { centred } \\
\text { teaching } \\
\text { method }\end{array}$ & 0.494 & & & \\
$\begin{array}{l}\text { Student- } \\
\text { centred } \\
\text { teaching } \\
\text { method }\end{array}$ & 0.521 & 0.664 & & \\
$\begin{array}{l}\text { Students' } \\
\text { Soft Skills }\end{array}$ & 0.793 & & 0.506 & \\
$\begin{array}{l}\text { Students' } \\
\text { Technical } \\
\text { Skills }\end{array}$ & 0.731 & 0.382 & 0.538 & \\
\hline
\end{tabular}

There has been some criticism of the Fornell-Larcker criterion, Henseler et al. (2015) mentioned that it does not accurately reveal the lack of discriminant validity in common research situations. They have proposed an alternative technique which is the heterotrait-monotrait ratio (HTMT) of correlations based on the multitrait-multimethod matrix. This study assesses discriminant validity through HTMT. 
Student-Centred, Lecturer-Centred, and Hybrid Teaching Methods: Impacts on Accounting...

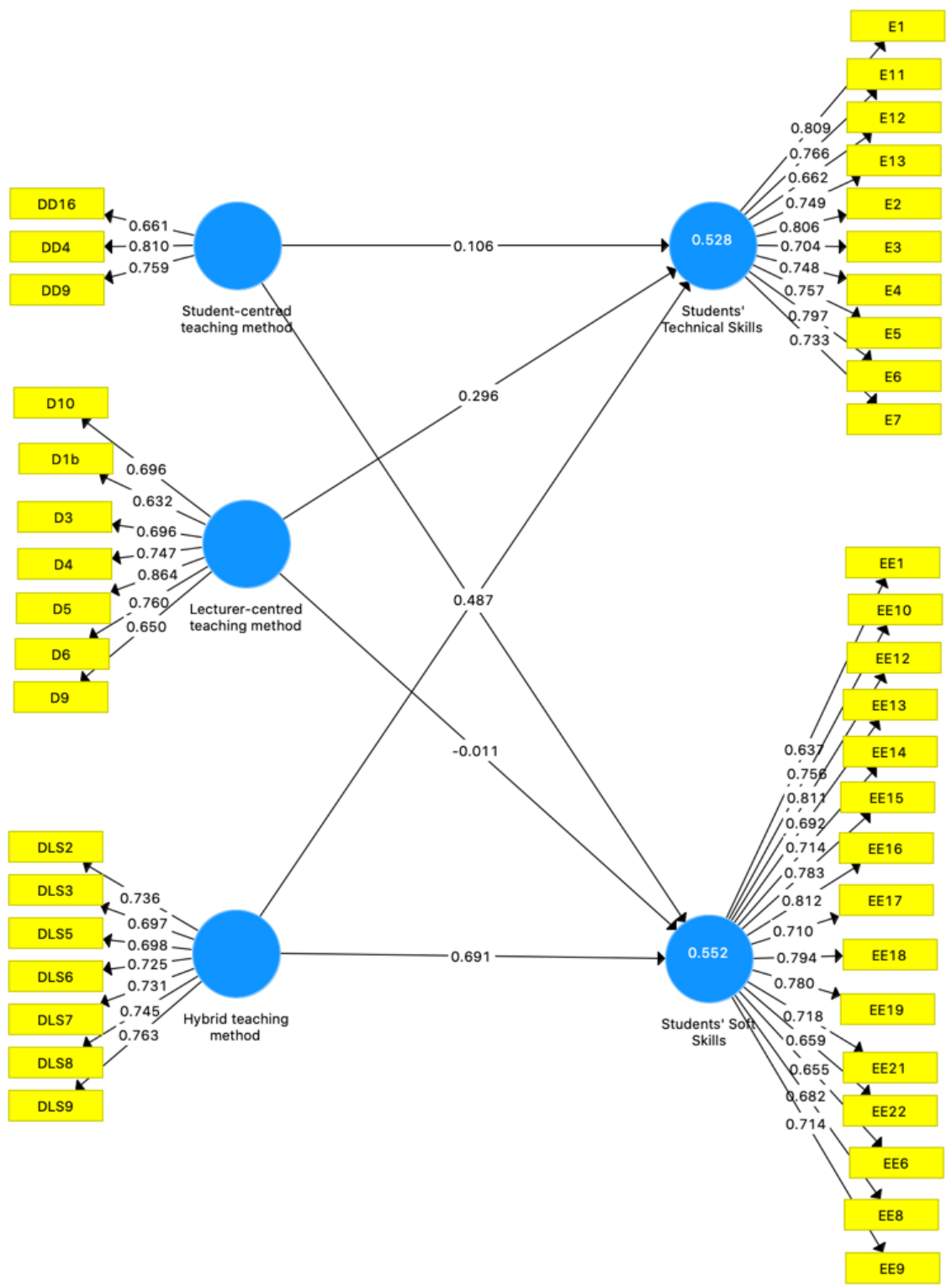

Figure 2 PLS algorithm results 


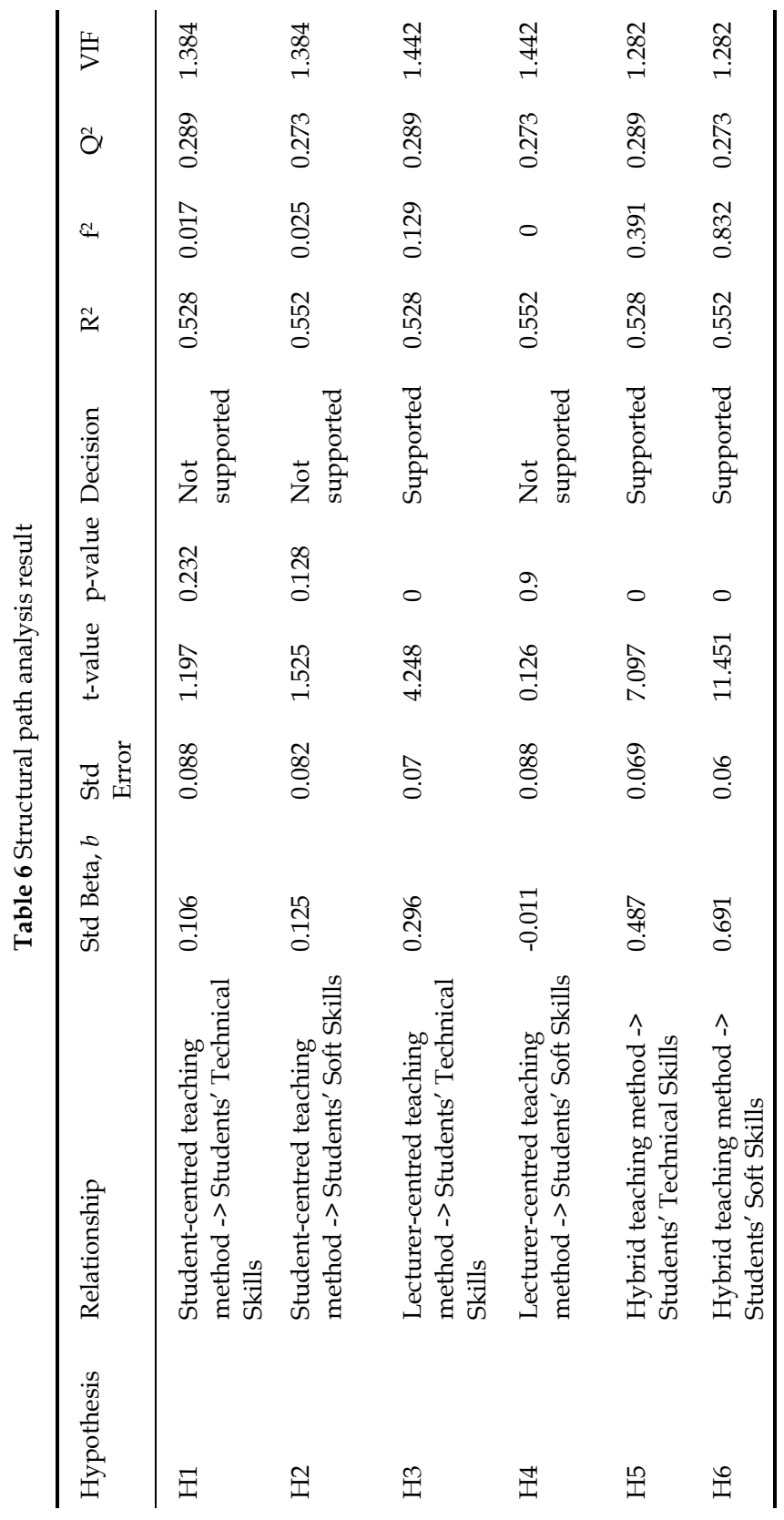


While the discriminant validity has a problem when the HTMT value is greater than HTMT value of 0.90 (Gold et al., 2001), or the HTMT value of 0.85 (Kline, 2010), all values as Table 5 shows were lower than the recommended value of 0.85 , indicating that discriminant validity has been ascertained.

\subsection{Structural Model Assessment}

Hair et al. (2017) suggested assessing the structural model by looking at the beta $(\beta), \mathrm{R}^{2}$ and the corresponding $\mathrm{t}$-values via a bootstrapping procedure with a resample of 500. Moreover, they recommend reporting the effect sizes $\left(\mathrm{f}^{2}\right)$ as well as the predictive relevance $\left(\mathrm{Q}^{2}\right)$. As Sullivan and Feinn (2012) argues, the p-value determines whether the effect exists, but it does not reveal the size of the effect.

\subsection{Hypotheses Tests}

The structural model assessment as depicted in Figure 2 and Table 6 provides the indication of the hypotheses tests. Of six hypotheses, three are accepted; H3, $\mathrm{H} 5$ and H6. Meanwhile, H1, H2 and H4 are not accepted. The lecturer-centred teaching method significantly predicts the performance of students in terms of technical skills thus $\mathrm{H} 3$ is accepted with $(\beta=0.296, \mathrm{t}=4.248, \mathrm{p}=0.000)$. Likewise, the hybrid teaching method significantly predicts the performance of students in both skills; technical skills and soft skills. Hence, H5 and H6 are supported $(\beta=0.487,0.691 ; \mathrm{t}=7.097,11.451 ; \mathrm{p}=0.000$ respectively).

The student-centred teaching method, lecturer-centred teaching method and hybrid teaching method explain $55.4 \%$ and $52.8 \%$ of the variance in students' technical skills and students' soft skills respectively. The $\mathrm{R}^{2}$ values achieved an acceptable level of explanatory power as recommended by Cohen (1988) and Chin (1998) indicating a substantial model.

This study also assessed effect sizes $\left(\mathrm{f}^{2}\right)$. Effect size $\mathrm{f}^{2}$ determines whether an exogenous latent construct has a substantial, moderate or weak impact on an endogenous latent construct (Gefen \& Rigdon, 2011). Hair et al. (2017) recommends to test the change in the $\mathrm{R}^{2}$ value. Cohen (1988) suggested as a guideline measure, a magnitude of $\mathrm{f}^{2}$ at 0.35 (large effects), 0.15 (medium effects) and 0.02 (small effects). The result of $\mathrm{f}^{2}$ as Table VI depicts, two relationships between 1 ) hybrid teaching method and students' technical skills and 2) hybrid teaching method and students' soft skills have large effect sizes. On the other hand, the student-centred teaching method has a medium effect on students' soft skills. The other relationships between the lecturer-centred and students' technical skills and soft skills, as well as relationship between the student-centred teaching method and students' technical skills have shown small effect sizes. 
Using the blindfolding procedure, this study examined the power of the proposed research model pertaining to predictive relevance. As recommended by Hair et al. (2017), the blindfolding procedure should only be used on endogenous constructs with a reflective measurement. If the value of $\mathrm{Q}^{2}$ is greater than 0 , then the predictive relevance of the proposed model exists for a certain endogenous construct (Fornell \& Cha, 1994; Hair et al., 2017). As Table VI shows all the values of $\mathrm{Q}^{2}$ range from 0.273 to 0.289 (greater than 0 ), this indicates that there is an adequate predictive relevance for the proposed model. For the $\mathrm{Q}^{2}$ values, Hair et al. (2017) suggests values of 0.35 (large), 0.15 (medium) and 0.02 (small) as a relative measure of predictive relevance. The result of this study shows that one endogenous construct has a medium predictive relevance and the other has small predictive relevance.

An issue of multi-collinearity could exist in any study. This is not desirable, as it means that the variance exogenous constructs explained in the endogenous construct are overlapping with each other and thus not explaining any unique variance in the endogenous variable ( $\mathrm{O}^{\prime}$ Brien, 2007). To measure and assess the degree of multi-collinearity, a variance inflation factor (VIF) is widely used (O'Brien, 2007). There is cause for concern when the largest VIF is greater than 10 (Bowerman, 1990; Myers, 1990). Hair et al. (2017) stated that a multicollinearity issue exists when the largest VIF is greater than 5 . The multicollinearity diagnostic through VIF indicates that there is no evidence of significant multi-collinearity among the study exogenous constructs because all VIF values are less than 5 (ranging from 1.000 to 2.901). This means that the variance of exogenous constructs explained in the endogenous construct are not overlapping with each other.

\section{Discussion of Findings}

The findings of this study will enhance the understanding of the teaching methods impacting accounting students' technical and soft skills in Malaysian public universities. This study also highlights relevant implications and suggestions for universities to review and assess the types of teaching method that is currently used in imparting knowledge to the accounting graduates. Therefore, revisiting and revising the current teaching methods is necessary to prepare future accountants for a career in accounting.

This study finds that the lecturer-centred teaching method significantly influences the students' technical skills as H3 is supported. This shows the significant role of educator in student learning in terms of disseminating direct information to a large working group of students (Andala \& Ng'umbi, 2016). Biggs (2012) explains about the phenomena in campus where they focus on student differences with the fact that there are the good students and the poor students. As lecturers, they should know their responsibilities in terms of understanding the contents of the courses and to expound them clearly. 
Therefore, this method can improve the performance of students' technical skills. The results of this study are consistent with past literature. Interestingly, the study also finds that the hybrid teaching method significantly influences both students' technical and soft skills as H5 and H6 are supported. Ganyaupfu (2013) defines the lecturer-student interactive method (known as hybrid method) as a teaching method that applies the strategies used by both teachercentred and student-centred approaches. The memorization of the information and knowledge produced by the learners are better than when the same information presented to the learners by the lecturer (Jacoby, 1978; McDaniel et al., 1978; Slamecka \& Graf, 1978). This method encourages the students to search for relevant knowledge as compared to the approach where the lecturer focuses on the transmission of information to the learners. As such, research evidence on teaching approaches maintains that this teaching method is effective in improving students' academic performance (Damodharan \& Rengarajan, 1999). The results of this study are consistent with the past literature. The findings are also consistent with the study by Ganyaupfu (2013) which reveals that combining both teacher-centred and student-centred teaching methods is the most effective approach in improving students' academic performance. In other words, the hybrid method can drive interactivity and entice the students to be active and revived them from their passivity of merely listening to lectures and make them attentive and engaged; two prerequisites for effective learning. Therefore, students' technical skills and soft skills can be improved through the implementation of this method of teaching as proven from the results of this study. The results of this study are also consistent with the findings by Wiggins (1987) which indicates that the interaction between the teacher and students during the teaching and learning process encourages the students to search for knowledge rather than depending on the lecturer to deliver information to them. The study by Fortin and Legault (2010) documented that the mixed approach to learning significantly enhanced competency levels of accounting students.

However, in this study, $\mathrm{H} 1$ and $\mathrm{H} 2$ are not supported which implies that student-centred teaching method does not significantly influence both students' technical and soft skills. H4 is also not supported which means that lecturer-centred teaching method does not significantly influence the students' soft skills. These findings highlight the disadvantages of this method in the teaching and learning process. A review of past literature shows that the lecturer-centred teaching method is problematic in that it fails to promote significant learning and does not engage students or motivate them to be accountable for their learning (Mukokera \& Nyantanga, 2016). Traditionally, teaching and learning is based on the teacher-centred method rather than the modern student-oriented approach and technique while the transmission of knowledge and information is through the usual form of lectures or discussions 
(Braun \& Sellers, 2012). The other disadvantage is that it inhibits the students' personal growth in the sense that the students do not have control over their own learning. In the study by Boud and Feletti (1999), it is found that in this method the students simply receive information from the lecturer without comprehending the contents of the subject being taught. According to Teo and Wong (2000), the lecturer-centred method lacks practicality and focuses on theory and memorization. There is no room for activity-based learning to motivate students in learning real life problems. The lecturer is directed towards maximizing the amount of information delivered while minimizing the amount of time and effort spent on the students due to the fact that the knowledge transfer is controlled by the lecturer. The results of the study are also consistent with the findings by Griffiths et al. (2007) that the application of the student-centred teaching method enhances student reliance and motivation. However, this study mentions one of the drawbacks of this method where the students felt that the lecturers may not provide sufficient guidance.

\section{Conclusion}

The research findings reveal that the hybrid teaching method has significant impact on accounting students technical and soft skills. While, the lecturercentred method is impacting the technical skills of the accounting students. This is to conclude that active involvement of lecturer and students in the learning process would be the most effective teaching method because it is able to enhance technical skills of the accounting students in the core courses of disciplines of accounting. In addition, the method is also able to develop communication, critical thinking, problem solving, leadership and teamwork skills of the accounting students.

Student-centred learning is found to be an ineffective method in impacting technical and soft skills of the accounting graduates. The results suggest that a teaching method that allows full control and responsibility of the students in the learning process is unable to enhance the students' competency in technical and soft skills. In addition, the lecturer-centred method is found to be insignificant in impacting students' soft skills. The results implied that a passive method of learning that includes inactive participation of students in the learning process is unable to enhance soft skills of the accounting students.

Overall, this study examined the effect of teaching methods on the technical and soft skills of accounting graduates. The evidence has shown that the lecturer-student teaching method has a greater influence on the technical and soft skills of accounting students. Hence, universities should review and assess the types of teaching methods that are currently used in imparting knowledge to the accounting graduates. Therefore, one of the implications of the findings is revisiting and revising the current teaching methods is necessary to prepare future accountants for a career in accounting. Lecturers should apply 
appropriate teaching methods that best suit specific objectives and learning outcomes in order to facilitate knowledge transmission. In addition, relevant groups in the accounting filed such as the ministry of higher education and universities should be able to use the results of this study as an input in setting up relevant teaching pedagogy policies related to the accounting programme. Further, appropriate trainings need to be provided to the lecturers as to enhance their skills and techniques in ensuring effective teaching methods are used in the delivery of the accounting knowledge in the class. The results of the study complement the existing body of knowledge by examining the effects of teaching methods in major accounting courses or disciplines on students' soft and technical skills.

There are several limitations to this study. First, the current study has only examined three research constructs that potentially affect the skills of accounting students in its specific course of disciplines and specific soft skills. Further work needs to be done to establish whether other factors such as students' traits, family traits and study approach may affect students' performance. Second, the sampling method adopted by this study is a convenience sampling basis which is limited to only one public university in Malaysia. As such, future research may be undertaken to broaden the size of respondents from different universities so that the research will be more representative. Perhaps samples could also be taken from both public and private universities, which will illuminate a better understanding of whether there are differences in the impact of teaching methods on the students' performance.

\section{Acknowledgements}

We would like to acknowledge the financial support provided by University of Malaya under the Equitable Society Research Cluster (ESRC) research grant RP042C-16SBS.

\section{References}

Abeysekara, I. (2015). Student preferences for instructional methods in an accounting curriculum. International Journal of Teaching and Learning in Higher Education, 27(3), 310-319.

Accounting Deans Council (2019). Accounting Graduates' Competency Framework. Universiti Sains Malaysia.

Adebayo, A. O, Mortimer, J. W., Marcis, J. G., \& Philip, L. (2015). The impact of student learning styles on scholastic performance. Journal of the Academy of Business Education, 16, 276-291.

Adunola, O. (2011). The impact of teachers' teaching methods on the academic performance of Primary School Pupils in Ijebu-Ode Local Cut Area of Ogun State. Ego Booster Books.

Ahmad, T. (2019). Scenario based approach to re-imagining future of higher education which prepares students for the future of work. Higher Education, Skills and Work-Based Learning, 10(1), 217-238. https:// doi.org/10.1108/HESWBL-12-2018-0136 
Albrecht, W. S., \& Sack, R. J. (2000). Accounting Education Series (16). Saratosa, Fla, American Accounting Association.

Andala, H. O., \& Ng'umbi, M. (2016). The teaching methods used in Universities in Ruwanda and their effects on the students' academic performance. IOSR Journal of Research and Method in Education (IOSR-JRME), 6(5), 13-22.

Anderson, J. C., \& Gerbing, D. W. (1988). Structural equation modeling in practice: A review and recommended two-step approach. Psychological Bulletin, 103(3), 411-423. https://doi.org/10.1037/0033-2909.103.3.411

Arquero, J. L., Donoso, J. A., Hassall, T., \& Joyce, J. (2001). Vocational skills in the accounting professional profile: The Chartered Institute of Management Accountants (CIMA) employers' opinion. Accounting Education: An International Journal, 10(3), 299-313. https:// doi.org/10.1080/09639280210122339

Awang, Z. (2014). Structural Equation Modeling Using AMOS. Penerbit Universiti Teknologi MARA.

Ayeni, A. J. (2011). Teachers professional development and quality assurance in Nigerian Secondary Schools. World Journal of Education, 1(2),143-149

Barac, K. (2009). South African training officers' perceptions of the knowledge and skills requirements of entry-level training accountants. Meditari Accountancy Research, 17(2), 1946. https:// doi.org/10.1108/10222529200900010

Barclay, D. W., Higgins, C., \& Thompson, R. (1995). The partial least square (PLS) approach to causal modeling: Personal computer adoption and use as an illustration. Technology Studies, 2(2), 285-309.

Biggs, J. (2012). What the student does: Teaching for enhanced learning. Higher Education Research and Development, 31(1), 39-55. https:// doi.org/10.1080/0729436990180105

Brown, J. K. (2008). Student-centered instruction: Involving students in their own education. Music Educators Journal, 94(5). https:// doi.org/10.1177\%2F00274321080940050108

Boud, D., \& Feletti, G. (1999). The Challenge of Problem-Based Learning, (2nd Ed.), London, Kogan Page.

Bowerman, B. L. (1990). Linear Statistical Models: An Applied Approach (2nd ed.). New York, London: PWS-Kent Pub. Co.

Braun, K. W., \& Sellers, R. D. (2012). Using a "Daily Motivational Quiz" to Increase Student Preparation, Attendance, and Participation. Issues in Accounting Education, 27(1), 267-279. https://doi.org/10.2308/iace-10219

Chien, T-K. (2007). Using the learning satisfaction improving model to enhance the teaching quality. Quality Assurance in Education, 15(2), 192-214. https://doi.org/10.1108/09684880710748947

Chin, W. W. (1998). The partial least squares approach for structural equation modelling. In G. A. Marcoulides (ed.), Modern Methods for Business Research (pp. 295-336). Lawrence Erlbaum Associates Publishers.

Clark, J. T. (2015). Undergraduate Accounting Students: Prepared for The Workplace?. Journal of International Education in Business, 8(1),37-48. https://doi.org/10.1108/JIEB-11-2013$\underline{0043}$

Clark, S. D., \& Latshaw, C. A. (2012). Effects of learning styles/teaching styles and effort on performance in accounting and marketing courses. World Journal of Management, 4(1), 6781. https:// doi.org/10.1016/j.sbspro.2012.12.122

Cohen, J. (1988). Statistical power analysis for the behavioral sciences (2nd Ed.). Routledge

Cortina, J. M. (1993). What is coefficient alpha? An examination of theory and applications. Journal of Applied Psychology, 78(1), 98-104. https://psycnet.apa.org/doi/10.1037/0021$\underline{9010.78 .1 .98}$ 
CSAP (2014). Report on the strengthening of the accountancy profession in Malaysia. The Committee to Strengthen the Accountancy Profession

Damodharan, V. S., \& Rengarajan, V. (1999). Innovative methods of teaching. National Research Council, Educational Journal Publication.

Dolce, V., Emanuel, F., Cisi, M., \& Ghislieri, C. (2020). The soft skills of accounting graduates: Perceptions versus expectations. Accounting Education, 29(1), 57-76. https://doi.org/10.1080/09639284.2019.1697937

Douglas, S., \& Gammie, E. (2019). An investigation into the development of non-technical skills by undergraduate accounting programmes. Accounting Education, 28(3), 304-332. https://doi.org/10.1080/09639284.2019.1605532

EPU (2015), 11 th Malaysia Plan (2016-2020) (Economic Planning Unit, Prime Minister's Department, 2015)

Farr-Wharton, B., Charles, M.B., Keast, R. Wollcott, G., \& Chamberlain, D. (2018), Why lecturers still matter: the impact of lecturer-student exchange on student engagement and intention to leave university prematurely, Higher Education, 75, 167-185. https://doi.org/10.1007/s10734-017-0190-5

Fornell, C., \& Larcker, D. F. (1981). Evaluating structural equation models with unobservable variables and measurement error. Journal of Marketing Research, 18(1), 39-50. https://doi.org/10.1177\%2F002224378101800104

Fornell, C., \& Cha, J. (1994). Partial Least Squares. In R. P. Bagozzi (Ed.), Advanced Methods in Marketing Research (pp. 52-78). Blackwell.

Fortin, A. \& Legault, M. (2010). Development of generic competencies: Impact of a mixed teaching approach on students' perceptions. Accounting Education, 19(1-2), 93-122. https:// doi.org/10.1080/09639280902888195

Gallo, A. (2012, November 29). How to Master a New Skill. Harvard Business Review. Available at: https:/ / hbr.org/2012/11/how-to-master-a-new-skill

Gammie, B., Gammie, E., \& Cargill, E. (2002). Personal skills development in the accounting curriculum. Accounting Education, 63-78. https://doi.org/10.1080/09639280210153272

Ganyaupfu, E. M. (2013). Teaching methods and students' academic performance. International Journal of Humanities and Social Science Invention, 2(9), 29-35.

Griffiths, G., Oates, B. J., \& Lockyer, M. (2007). Evolving a facilitation process towards student centred learning: A case study in computing. Journal of Information Systems Education, 18(4), 459-467.

Gold, A. H., Malhotra, A., \& Segars, A. H. (2001). Knowledge management: An organizational capabilities perspective. Journal of Management Information Systems, 18(1), 185-214. https:// doi.org/10.1080/07421222.2001.11045669

Hair, J. F., Hult, G. T. M., Ringle, C., \& Sarstedt, M. (2017). A primer on partial least squares structural equation modeling (PLS-SEM) (2nd Ed.). SAGE.

Hair, J. F., Black, W. C., Babin, B. J., \& Anderson, R. E. (2010). Multivariate Data Analysis (7th Ed.). Pearson.

Hair, J. F., Black, B., Babin, B., Anderson, R. E., \& Tatham, R. L. (2006). Multivariate data analysis (6 ${ }^{\text {th }}$ Ed.). Prentice-Hall International Inc.

Hanafi, M. (2007). PLS path modelling: Computation of latent variables with the estimation Mode B. Computational Statistics, 22(2), 275-292. https://doi.org/10.1007/s00180-007$\underline{0042-3}$

Harvey, L., \& Knight, P.T. (1996). Transforming Higher Education, The Society for Research in Higher Education and Open University Press, Buckingham. 
Henseler, J., Ringle, C. M., \& Sinkovics, R. R. (2009). The use of partial least squares path modeling in international marketing. Advances in International Marketing, 20(1) 277-319. https://doi.org/10.1108/S1474-7979(2009)0000020014

Hopland, A. O., \& Nyhus, O. H. (2016). Learning environment and student effort. International Journal of Educational Management, 30(2), 271-286. https://doi.org/10.1108/IJEM-05-2014$\underline{0070}$

Howieson, B. (2003). Accounting practice in the new millennium: Is accounting education ready to meet the new challenge?. The British Accounting Review, 35(2), 69-103. https://doi.org/10.1016/S0890-8389(03)00004-0

International Federation of Accountants (IFAC). (2010). International Education Standard (3): Professional Skills and General Education. IFAC.

Ismail, S. (2013). The importance of soft skills for accounting students in Malaysia. Journal of Accounting Perspectives, 6, 1-11. https:// doi.org/10.22452/AJAP.vol6no1.1

Ismail, I. R. B., Hamid, R. R. A., \& Idris, F. (2012). PLS Application in journal of operations management: A review. Paper presented to Global Conference on Operations and Supply Management (GCOM 2012), Bandung, Indonesia, 12-13 March 2012.

Jacobsen, D. A., Eggen, P., \& Kauchak, D. (2009). Methods for teaching promoting student. Learning in K-12 Classrooms (8 ${ }^{\text {th }}$ Ed.). Library of Congress Cataloging-in-Publication Data. Pearson Education, Inc.

Jacoby, L. L. (1978). On interpreting the effects of repetition: Solving a problem versus remembering a solution. Journal of Verbal Learning and Verbal Behavior, 17, 649-667. https://doi.org/10.1016/S0022-5371(78)90393-6

Jepsen, D. M., Varhegyi, M. M., \& Stephen, T. T. (2015). The association between learning styles and perception of teaching quality. Education and Training, 57(5), 575-587. https://doi.org/10.1108/ET-02-2014-0005

Kline, R. B. (2010). Principles and Practice of Structural Equation Modeling (3rd Ed.). The Guilford Press.

Kutner, M. H., Nachtsheim, C. J. \& Neter, J. (2003). Applied Linear Regression Models (4th ed.). McGraw Hill.

Lehner, F., \& Haas, N. (2010). Knowledge management success factors-proposal of an empirical research. Electronic Journal of Knowledge Management, 8(1), 79-90.

Lin, X. F. (1997), School Management and Education Quality. Modern Education Forum III, 245-248.

Ministry of Higher Education (MOHE) (2015). Report of Review of Bachelor's Program Accounting Institution of Higher Education Malaysia 2013.

Malaysian Institute of Accountants Competency Framework (MIA CF) (2020) accessed at https://www.mia.org.my/v2/Education/competency.aspx

Malhotra, N. K. (2010). Marketing Research: An Applied Orientation (6 ${ }^{\text {th }}$ Ed.). Prentice-Hall International Inc.

Maelah, R., Aman, A., Mohamed, Z. M., \& Ramli, R. (2012). Enhancing soft skills of accounting undergraduates through industrial training. Procedia Social and Behavioral Sciences, 59, 541549. https://doi.org/10.1016/j.sbspro.2012.09.312

McDaniel, M. A., Friedman, A., \& Bourne, L. (1978). Remembering the levels of information in words. Memory and Cognition, 6, 156-164. https://doi.org/10.3758/BF03197441

Moore, R. (2007). Academic motivation and performance of developmental education biology students. Journal of Developmental Education, 31(1), 24-34.

Mukorera, S., \& Nyatanga, P. (2016). Students' Perception of Teaching and Learning Practises: A Principal Component Approach. SAEF Working Paper No. 2016/01/11

Myers, R. H. (1990). Classical and Modern Regression with Applications (2nd ed.). Boston: MA: Duxbury. 
Nadkarni, S. (2003). Instructional methods and mental models of students: An empirical investigation. Academy of Management Learning and Education, 2(4), 335-35. https://doi.org/10.5465/amle.2003.11901953

Ngoo, Y.T., Tiong, K.M., \& Pok, W.F. (2015). Bridging the gap of perceived skills between employers and accounting graduates in Malaysia. American Journal of Economics, 5(2), 98 104. https://doi.org/10.5923/c.economics.201501.09

Nunnally, J. O. (1978). Psychometric Theory. McGraw-Hill.

$\mathrm{O}^{\prime}$ brien, R. M. (2007). A caution regarding rules of thumb for variance inflation factors. Quality and Quantity, 41(5), 673-690. https:// doi.org/10.1007/s11135-006-9018-6

O'Leary, C., \& Stewart, J. (2013). The interaction of learning styles and teaching methodologies in accounting ethical instruction. Journal Busisness Ethics, (113), 225-241. https://doi.org/10.1007/s10551-012-1291-9

Pallant, J. (2011). SPPS Survival Manual: A Step by Step Guide To Data Analysis Using SPSS (4th ed.). Everbest Printing Co.

Parker, D. L. (2001). Back to the future: The broadening accounting trajectory. British Accounting Review, 33(4), 421-453. https:// doi.org/10.1006/bare.2001.0173

Ramsarghey, K. (2020). What educator capabilities are necessary for reflective learning in accounting students?. South African Journal of Higher Education, 34, 230-247. http://dx.doi.org/10.20853/34-2-3336

Reschiwati \& Zahri, M. (2019). The effect of teaching methods and learning motivation on accounting learning achievement in terms of student perceptions. Malaysian Journal of Consumer and Family Economics, 258-274.

Ringle, C. M., Wende, S., \& Becker, J.-M. (2015). SmartPLS 3. Bonningstedt: SmartPLS. Retrieved from http://www.smartpls.com

Scarcella, R. \& Oxford, R. (1992) The Tapestry of Language Learning: The Individual in the Communicative Classroom. Heinle \& Heinle Publisher.

Schumacker, R. E., \& Lomax, R. G. (2004). A Beginner's Guide to Structural Equation Modeling. Lawrence Erlbaum.

Serin, H. (2018). A comparison of teacher-centered and student-centered approaches in educational settings. International Journal of Social Sciences \& Educational Studies, 5(1), 164167. http://doi.org/10.23918/ijsses.v5i1p164

Shamsuddin, A., Mohamad Ibrahim, M. I., \& Ghazali, M.H. (2015). Employers' level of satisfaction towards accounting graduates. South East Asia Journal of Contemporary Business, Economics and Law, 7(1), 22-30.

Slamecka, N. J., \& Graf, P. (1978). The generation effect: Delineation of a phenomenon. Journal of Experimental Psychology: Human Learning and Memory, 4(6), 592-604.

Stainbank, L. J. (2009). Working in teams: Improving the team experience. Meditari Accountancy Research, 17(1), 69-80. https:// doi.org/10.1108/10222529200900005

Sullivan, G. M., \& Feinn, R. (2012). Using effect size - or why the p value is not enough. Journal of Graduate Medical Education, 4(3), 279-282. https://dx.doi.org/10.4300\%2FJGME-D-1200156.1

Teo, R., \& Wong, A. (2000). Does problem based learning create a better student: A reflection?. Paper presented at the $2^{\text {nd }}$ Asia Pacific Conference on Problem Based Learning: Education Across Disciplines, December 4-7, Singapore.

Van der Merwe, D. (2012). The usefulness of student evaluations for enhancing the effectiveness of teaching of financial accounting students at a South African University. Research in Accounting in Emerging Economies 12 (A), 107-126. https:// doi.org/10.1108/S1479-3563(2012)000012A009 
Villiers, R. (2010). The incorporation of soft skills into accounting curricula: Preparing accounting graduates for their unpredictable futures. Meditari Accountancy Research, 18(2), 1-22. https:// doi.org/10.1108/10222529201000007

World Bank (2012). The Report on Observance of Standards and Codes, Accounting and Auditing. Washington, USA.

Warner, T., \& Palmer, E. (2015). Personalising learning: Exploring student and teacher perceptions about flexible learning and assessment in a flipped university course. Computers and Education, 88, 354-369. https://doi.org/10.1016/i.compedu.2015.07.008

Watts, M., \& Schaur, G. (2011). Teaching and assessment methods in undergraduate economics: A fourth national quinquennial survey. The Journal of Economic Education, 42(3), 294-309. https:// doi.org/10.1080/00220485.2011.581956

Watty, K. (2005). Quality in accounting education: What say the academics?. Quality Assurance in Education, 13(2), 120-131. https:// doi.org/10.1108/09684880510594373

Weber, M. R., Finely, D. A., Crawford, A., \& Rivera, D. J. (2009). An exploratory study identifying soft skill competencies in entry-level managers. Tourism and Hospitality Research, 9(4),353-361. https:// doi.org/10.1057\%2Fthr.2009.22

Wetzels, M., Odekerken-Schroder, G., \& Van Oppen, C. (2009). Using PLS path modeling for assessing hierarchical construct models: Guidelines and empirical illustration. MISQ, 33(1), 177. https:// doi.org/10.2307/20650284

Wiggins, G. (1987). Creating a thought - provoking curriculum. American Educator, Winter, 10-17.

Wolk, R. (2010). Education: the case for making it personal. Educational Leadership, 67(7), 16-21.

Yue, J. Y. (2020). Research on the reform of accounting teaching mode under the impact of artificial intelligence. Journal of Physics: Conference Series, 1-5. https://doi.org/10.1088/1742-6596/1651/1/012003 